\title{
СПЕЦИФІКА СЕМАНТИЧНИХ ПРОЦЕСІВ В УКРАЇНСЬКІЙ НАУКОВО-ТЕХНІЧНІЙ ТЕРМІНОЛОГІЇ
}

У статті досліджено семантичні процеси як чинники розвитку термінологічної лексики. Розглянуто специфіку таких семантичних процесів, як розширення, звуження й зміщення значення у сфері української науковотехнічної термінологіі. На численних прикладах продемонстровано, що семантичний прочес розширення значення в термінології супроводжується детермінізацією й ретермінізацією, процес звуження значення - термінізацією й ретермінізацією, а процес змішення - термінізацією, ретермінізацією й транстермінізачією. Доведено, що мотивують семантичні процеси в термінології метафоричне переосмислення й метонімне зрушення вихідних значень.

Ключові слова: семантичні процеси, термінологія, розщирення значення, звуження значення, змімення значення, метафора, метонімія.

Krymets O. Characteristic Aspects of Semantic Processes in Ukrainian Scientific and Technical Terminology. The topicality of the research lies in the study of semantic processes as factors in the development of terminological vocabulary and the analyses of changes that give rise to new meanings, which reflect the progressive development of science and technology and feature the principles of categorization of relevant fragments of objective reality in the semantic structure of special naming units.

The purpose of the article is to determine the specificity of semantic processes in Ukrainian scientific and technical terminology. The task of the study is to characterize the semantic processes of extension, narrowing and shifting of the term and common word meanings, to determine the motivator of this process and the characteristics of semantic processes in the field of terminological vocabulary.

The results of the research have shown that terms as well as common words have such semantic processes as extension, narrowing, and shifting of the meaning. The extension of the term causes a new, commonly used word (which could change the meaning of the word for better or worse) or a new term. When narrowing the meaning of the word, a commonly used word or term is reinterpreted with a broad meaning. The semantic process of the meaning shift is characteristic of both common and special names. These processes are motivated by the metaphorical reinterpretation that occurs on the basis of similarity of function or appearance, as well as metonymic shifts, in particular such models as " $X-X$ where it is used", " $X-$ containing X", "repository - content", "science is the object matter", "part - whole", and others. 
Characteristic aspects of semantic processes in the field of Ukrainian scientific and technical terminology lie in the fact that the extension, narrowing or shift of the meaning, result in termination, determination, retermination, and transtermination of the original word. The emergence of a new terminological or common meaning is the result of these processes.

Key words: semantic processes, terminology, extension of the meaning, narrowing of the meaning, shift of the meaning, metaphoric expression, metonymy.

\section{Вступ}

Одним із чинників розвитку лексичної системи української мови є семантичні процеси, за допомогою яких розв'язуються проблеми, що виникають між, з одного боку, кінечною множиною мовних знаків і зафіксованим у них результатом пізнавальної діяльності людини та, 3 другого боку, практично необмеженим континуумом нових сенсів, понять, значень, які щоразу народжуються в нових умовах життєдіяльності українського етносу. Термінам як одиницям спеціальної лексики також властиві семантичні процеси, завдяки яким виникають нові значення, що відбиває поступальний розвиток науки й техніки та відображає в семантичній структурі спеціальних номінацій принципи категоризації відповідних фрагментів об’єктивної дійсності.

Семантичними процесами в широкому мовознавчому розумінні цього терміна називають «історично зумовлену зміну значень слів. Причина зміни слова полягає в його вживанні. На момент створення слова наявний неповний збіг словотвірного і лексичного значення. Вживання слова в різних умовах спілкування зумовлює збагачення семантичної структури слова та окремих його значень» (Загнітко, 2012: 426). При цьому, за твердженням А. Загнітка, відбуваються протилежні семантичні процеси - розширення й звуження значення слова, у результаті яких виникають нові значення (Загнітко, 2012: 426). Окрім цих двох процесів, можна виокремити третій - зміщення значення, що грунтується на уяві про зв'язок між реаліями, унаслідок чого найменування одного поняття застосовується як назва іншого. На думку науковців, мотивують семантичні процеси метафора та метонімія (Ульманн, 1970; Загнітко, 2012: 426).

В українському термінознавстві семантичні процеси досліджені спорадично, на прикладі окремих терміносистем. Слід зазначити, що під семантичними процесами в термінології науковці розуміють метафоризацію, метонімізацію, транстермінізацію (зміна значення 
термінів унаслідок запозичення з інших галузей науки або техніки), детермінізацію (перехід терміна до стану загальновживаних слів), термінізацію (перехід лексичної одиниці зі стану нетерміна до стану терміна), транспозицію (використання однієї мовної форми у функції іншої) (Касяненко, 2013; Гуменюк, 2016; Petrova, 2019).

Мета статті - дослідити основні семантичні процеси, що відбуваються в українській науково-технічній термінології й визначити їхню специфіку. Завдання дослідження - схарактеризувати семантичні процеси розширення, звуження й зміщення значення терміна та загальновживаного слова, визначити, що їх мотивує і якими особливостями характеризуються семантичні процеси у сфері термінологічної лексики.

\section{Методи та методики дослідження}

У дослідженні термінологічної лексики застосовано методи й прийоми номінативного, елементи когнітивного аналізу за широкого застосування опозиційного методу; аналітико-описовий метод для вивчення кожної термінологічної одиниці в структурному й семантичному аспектах, а також для узагальнення й класифікації мовних фактів. Для дослідження плану змісту українських технічних термінів, уточнення їхньої семантичної структури залучено методи дефінітивного аналізу й прийоми компонентного аналізу.

\section{Результати та дискусії}

Вважаємо за доцільне у сфері термінології виокремити три семантичні процеси: розширення, звуження й зміщення значення слова, що відбуваються шляхом метафоричного переосмислення або метонімного зрушення вихідного значення.

Розширення значення науковці визначають як перехід від видового значення до родового, тобто узагальнення, об’єднання, генералізацію, а також збільшення обсягу позначуваного поняття, що зумовлює виникнення нового значення слова (Загнітко, 2012: 238). У сфері термінологічної лексики розширення семантичного значення супроводжується детермінізацією спеціального значення - перенесенням значення терміна на нову одиницю побутового словника. Унаслідок цього виникає нове загальновживане значення, що за семантичним обсягом ширше за вихідне термінологічне. Літературознавчий термін пародія позначає: 'Жанр сатиричної і гумористичної літератури, 
заснований на перебільшено комічному наслідуванні твору якогось автора або літературного напряму' (ССIC). Унаслідок переосмислення цього значення виникло нове - загальновживане, що має менше сем, а значить, ширше за обсягом: 'Невдале, лише зовнішнє наслідування, яке спотворює сутність того, що наслідують' (CCIC).

Розгляньмо процес розширення значення на прикладі термінів різних галузей знань, а також схарактеризуймо семантичні зміни, що відбуваються в процесі цього, з'ясуймо, які одиниці утворюються внаслідок переосмислення значень наявних у мові термінів. Підставою для розширення значення спеціальних назв, а отже, і детермінізації $€$ широке впровадження досягнень науки й техніки в наше повсякденне життя, що спричиняє освоєння термінів, застосування ï у різних стилях мови, переосмислення й утворення нових загальновживаних значень.

Розширення значення зазнають терміни гуманітарних (nародія, проза, трагікомедія, контекст, макаронізм, схоластика, матерія, метабізика, експансія, меланхолік, конкуренція), точних (елімінація, ігрек), природничих (магніт, інериія, скорпіон, хамелеон) наук, а також таких галузей діяльності людини, як військова справа (тактик, рейд, ешелон), медицина (стерильний, рецицив, симптом), техніка (блокувати, автомат, баласт) та інших. Семантичний процес розширення значення терміна мотивується метафоричним перенесенням. Зокрема, термін морської справи лавірувати має таке значення: 'Вести судно з частою зміною курсу (напряму), минаючи перешкоди' (ССІС). Унаслідок метафоричного переосмислення терміна відбулося розширення значення й з'явилося два нових загальновживаних: 'Рухатися непрямо, обходячи перешкоди', 'перен. Ухилятися від прямої відповіді, дії; уникати конфліктів; уміло долати перешкоди’ (CCIC). Семою-мотиватором у процесі метафоризації слугує сема «минаючи перешкоди», семантичне перенесення відбулося на підставі схожості функції. У результаті заміни семи «вести» в термінологічному значенні на сему «рухатися» відбулося розширення значення, а внаслідок анігіляції спеціальних сем «судно», «курс» - спрощення й утворення в такий спосіб загальновживаного значення.

У поодиноких випадках спостерігаємо розширення значення терміна й утворення не загальновживаного, а іншого термінологічного значення, тобто відбувається процес ретермінізації. 
Загальнотехнічний термін шайба в початковому значенні виражає більш вузьке поняття, ніж у похідному: 'прокладка під гайку або головку гвинта, яка має форму плоского кільця // будь-яка прокладка такої форми' (ВТССУМ).

Семантичний процес розширення термінологічного значення може супроводжуватися погіршенням (негативацією) або покращенням (позитивацією) значення слова. Термін кулінарії маринування позначає 'спосіб виготовлення консервів шляхом додаванням до продуктів соусу з оцтовою кислотою, яка за певної концентрації в присутності солі пригнічує життєдіяльність організмів' (CСIC). Унаслідок розширення, мотивованого метафорою, виникло нове загальновживане значення: 'Вимушене неробство, томління в невідомості' (CCIC). У процесі творення похідного значення відбулася анігіляція багатьох сем, натомість з'явилися нові, що містять негативні оцінно-експресивні компоненти: «неробство», «томління». У деяких випадках відбувається позитивація похідного значення: котируватися - 'бути в обігу на біржі // перен. Цінитися, мати ту або іншу оцінку з боку даної групи людей, суспільства' (ССIC).

Семантичний процес розширення термінологічного значення може мотивуватися не лише метафорою, а й метонімією, тобто перенесенням найменування за суміжністю, що здійснюється на грунті постійного зв'язку в часі й просторі двох предметів, їхніх частин, дій та результатів (Загнітко, 2012: 426). Відомо, що метонімія як спосіб розвитку нових значень характеризується великим розмаїттям моделей полісемії. Розширення початкового значення спостерігається під час метонімного зрушення, зокрема за такими моделями: «X - X, де він використовується» й «Х - який містить Х». Термін асбальт позначає '1. Чорну смолисту масу природного походження або штучно виготовлена з бітуму й тонкоподрібнених мінеральних матеріалів. 2. Шлях, тротуар, покриті цією масою' (ВТССУМ); термін танкерний - 'який $є$ танкером. Танкерний корабель // який складається з танкерів’ (ВТССУМ). Метонімній моделі типу «частина - ціле» також притаманне розширення вихідного значення: термін фанера - '1. Деревинний матеріал у вигляді тонких пластин, якими обклеюють столярні вироби для їх оздоблення. 2. Деревинний матеріал із кількох склеєних тонких пластин із перехресним розташуванням волокон' (ВТССУМ). 
О. Тараненко зазначає, що в процесі метонімії може відбуватися й генералізація - перехід до відповідного родового, узагальненого значення (залізо - у розмовному стилі «метал взагалі»), і спеціалізація - конкретизація лексичного значення (звір у значенні «вовк», «ведмідь», «лось» у різних місцевостях) (Тараненко, 1989). Звуження значення, стверджує С. Ульманн, - у цілому більш звичний факт, ніж розширення, пояснюється це тим, що домінуючою тенденцією є розвиток у бік диференціації, а не в бік узагальнення (Ульманн, 1970: 281).

Звуження значення відбувається внаслідок переосмислення загальновживаного слова й супроводжується термінізацією. Проілюструємо це конкретними прикладами. Шляхом переосмислення більш широкого загальномовного значення слова отвір ('пусте, відкрите місце в чому-небудь суцільному; діра, відтулина, щілина') у технічній сфері утворилося більш вузьке спеціальне значення: 'мет. Місце в доменній печі, через яке випускають метал або шлак; льотка’ (ВТССУМ). Слово декор у початковому значенні виражає широке поняття: 'система декораційних елементів; прикраса' (ВТССУМ), а в похідному більш вузьке, конкретне - 'декоративний шрифт, основні штрихи якого прикрашені зображальними елементами’ (АУТРВКТ).

Ретермінізація, коли початковим виступає загальнотехнічний термін, а похідним - термін певної підгалузі техніки, також притаманна звуженню семантики вихідного слова. Зокрема термін з'єднувач у техніці позначає 'пристрій для з’єднування чого-небудь' (ВТССУМ), а в галузі комп'ютерної техніки - 'елемент, який забезпечує нерознімне з’єднання провідників мідного кабелю з електричними контактами' (АУТСОТІП). Термін ізохронний у процесі переосмислення також зазнав звуження початкового значення: 'який має однакову тривалість із чим-небудь іншим' (ВТССУМ), 'у телекомунікації - пересилання з однорідним тактуванням, наприклад, ізохронні відеота мовний трафіки' (АУТСОТІП). Мотиватором у процесі звуження значення слова слугує метафора.

Звуження початкового значення мотивує також метонімія, зокрема такі їі типи, як «вмістище - вміст»: вагон - '1. Спеціально устатковане приміщення для перевезення людей і вантажу рейковими коліями. 2. Кількість вантажу, що входить у товарний вагон' (ВТССУМ), «наука - об'єкт вивчення»: сурдотехніка - '1. Розділ дефектології, що розробляє технічні засоби навчання, коригування та компенсації дефектів 
слуху. 2. Сукупність технічних засобів, призначених для корекції або компенсації дефектів слуху' (ВТССУМ), «спеціалізоване приміщення артефакти, необхідні для використання приміщення за його функцією», ворсувальня: '1. Приміщення, в якому ворсують тканини. 2. Машина для ворсування тканин’ (ВТССУМ).

Семантичний процес зміщення значення у сфері термінологічної лексики супроводжується термінізацією, транстермінізацією й ретермінізацією загальновживаних та спеціальних назв відповідно. Загальномовне слово бочка має значення 'велика дерев'яна або металева циліндрична посудина, переважно опукла посередині, з двома плоскими днищами' (РУТСПВС). Унаслідок метафоричного переосмислення й зміщення з'явилося термінологічне значення: 'транспортна тара з корпусом циліндричної або параболічної форми, з обручами катання, з днищами' (РУТСПВС). Подібні процеси відбуваються й під час транстермінізації, коли початковим для творення технічного терміна $€$ термін іншої галузі людської діяльності: у медицині термін виразка позначає 'ранка на шкірі або на слизовий оболонці (від поранення, хімічного ураження, інфекційного захворювання й т. ін.)' (ВТССУМ), а в техніці - 'місцеве корозійне зруйнування у формі окремої виїмки, глибина якої приблизно дорівнює ширині' (ТРУАССПЗГ). Зміщення значень відбувається й під час ретермінізації: термін цанга у своєму початковому значенні - 'пристрій, призначений для затискання деталі або інструмента на металорізальному верстаті', а в похідному 'пристрій (патрон), що його використовують у сучасних побутових і професійних електроінструментах’ (ВТССУМ). У розглянутих прикладах зміщення значень мотивуються метафорою.

Зміщення можуть мотивуватися й метонімією: автотипія '1. Поліграфічний спосіб відтворення півтонових зображень, за якого растровий сітчастий негатив копіюють на цинкову пластинку, яку потім травлять азотною кислотою, створюючи кліше. 2. Відбиток такого кліше' (ВТССУМ); алебастровий - 'зроблений з алебастру // який виробляє алебастр' (ВТССУМ); нарізний - '1. Який має на своїй поверхні нарізи. 2. Якого використовують для нарізування’ (ВТССУМ); зашпунтовувати: 'буд. Робити шпунти, виступи або пази на ребрі дошок // З’єднувати дошки за допомогою шпунтів’ (ВТССУМ). 


\section{Висновки}

Отже, у сфері термінологічної лексики відбуваються семантичні процеси розширення, звуження й зміщення значення, що мотивуються метафоричним переосмисленням або метонімним зрушенням, результатом яких $є$ поява нового термінологічного або загальновживаного значення. Як і в загальновживаній лексиці, у термінології під час семантичних процесів може відбуватися погіршення або покращення значення, проте лише під час розширення й детермінологізації спеціального значення. Специфічними для термінологічної лексики $€$ термінізація, детермінізація, ретермінізація й транстермінізація, що супроводжують семантичні процеси розширення, звуження або зміщення значення.

\section{Список умовних скорочень}

АУТСОТІП - Англо-український тлумачний словник з обчислювальної техніки, Інтернету і програмування. Уклад. Е. І. Пройдаков, Л. А. Теплицький. Київ: СофтПрес, 2005. $552 \mathrm{c}$.

АУТСРВКТ - Англо-український тлумачний словник редакційно-видавничої комп’ютерної термінології. Уклад. В. Е. Шевченко. Київ: Либідь, 2006. 320 с.

ВТССУМ - Великий тлумачний словник сучасної української мови. Уклад. і гол. ред. В. Т. Бусел. Київ: Ірпінь, 2001. 1440 с.

РУТСПВС - Російсько-український тлумачний словник. Поліграфія та видавнича справа. Уклад. Б. В. Дурняк, О. В. Мельников, О. М. Василишин, О. Г. Дячок. Львів: Афіша, 2002. 456 с.

ССІС - Сучасний словник іншомовних слів. Уклад. Л. І. Нечволод. Харків: ПП «Торсінг плюс», 2007. 768 с.

ТРУАСПЗГ - Тлумачний російсько-українсько-англійський словник із протикорозійного захисту газопроводів. Уклад. М. Д. Гінзбург, М. В. Чернець, I. М. Корніловська та ін. Харків: Б. в., 2000. 616 с.

\section{ЛIТЕРАТУРА}

1. Гуменюк Т. І. Лексико-семантичні процеси в сучасній телевізійній фаховій мові. Мова: класичне - модерне - постмодерне. 2016. Вип. 2. С. 262-269. 2. Загнітко А. Словник сучасної лінгвістики: поняття і терміни. Донецьк : ДонНУ, 2012. Т. 3. 426 с. 3. Касяненко Д. Лексико-семантичні процеси в термінології правового євролекту та їхнє відтворення у перекладі. Мовні і концептуальні картини світу. 2013. Вип 2. С. 159-165. 4. Тараненко А. А. Языковая семантика в ее динамических аспектах. Київ: Наук. думка, 1989. 256 с. 5. Ульманн С. Семантические универсалии. Новое в тингвистике. 1970. Вып. 5. С. 250-299. 6. Petrova T. Melioration Terminology in Ukraine Scientific Picture of the World. Przeglad Wschodnoeuropejski (East European Review). 2019. X/2. S. 337-348. 


\section{REFERENCES}

1. Humeniuk, T. I. (2016). Leksyko-semantychni protsesy v suchasnii televiziinii fakhovii movi [Lexical and Semantic Processes in Modern Television Professional Language]. Mova: klasychne - moderne - postmoderne - Language: Classic - Modern - Postmodern, 2, 262-269 [in Ukrainian]. 2. Kasianenko, D. (2013). Leksyko-semantychni protsesy $\mathrm{v}$ terminolohii pravovoho yevrolektu ta yikhnie vidtvorennia u perekladi [Lexical and Semantic Processes in Law Verminology in European vocabulary and their Reproduction in Translation]. Movni i kontseptualni kartyny svitu - Linguistic and conceptual pictures of the world, 2, 159 - 165 [in Ukrainian]. 3. Petrova, T. (2019). Melioration Terminology in Ukraine Scientific Picture of the World. Przeglad Wschodnoeuropejski (East European Review), X/2. S. 337-348 [in English]. 4. Taranenko, A. A. (1989). Yazykovaya semantika v ee dinamicheskix aspektax [Language Semantics in its Dynamic aApects]. Kyiv: Nauk. dumka [in Russian]. 5. Ulman, S. (1970). Semantycheskye unyversalyy [Semantic Universals]. Novoe v lynhvystyke - New in Linguistics, 5, 250 - 299 [in Russian]. 6. Zahnitko, A. (2012). Slovnyk suchasnoi linhvistyky: poniattia i terminy [Modern Linguistics Dictionary: concepts and terms]. (Vol. 3). Donetsk: DonNU [in Ukrainian].

Кримець Оксана Михайлівна - кандидат філологічних наук, доцент, доцент кафедри української, російської мов та прикладної лінгвістики, Національний технічний університет «Харківський політехнічний інститут»; вул. Кирпичова, 2, м. Харків, 61000, Україна.

Tel.: +38-050-186-12-03

E-mail: oksana.krim@ukr.net

https://orcid.org/0000-0002-8401-3540

Krymets Oksana - PhD in Philology, Associate Professor, Department of Ukrainian and Russian Languages and Applied Linguistics, National Technical University "Kharkiv Polytechnic Institute"; Kyrpychov Str. 2, Kharkiv, 61000, Ukraine.

Надійшла до редакції 10 лютого 2020 року 